\title{
Insulin-Independent $\mathrm{GABA}_{\mathrm{A}}$ Receptor-Mediated Response in the Barrel Cortex of Mice with Impaired Met Activity
}

\author{
Fu-Sun Lo, Reha S. Erzurumlu, and Elizabeth M. Powell \\ Department of Anatomy and Neurobiology, University of Maryland School of Medicine, Baltimore, Maryland 21201
}

Autism spectrum disorder (ASD) is a neurodevelopmental disorder caused by genetic variants, susceptibility alleles, and environmental perturbations. The autism associated gene MET tyrosine kinase has been implicated in many behavioral domains and endophenotypes of autism, including abnormal neural signaling in human sensory cortex. We investigated somatosensory thalamocortical synaptic communication in mice deficient in Met activity in cortical excitatory neurons to gain insights into aberrant somatosensation characteristic of ASD. The ratio of excitation to inhibition is dramatically increased due to decreased postsynaptic $\mathrm{GABA}_{\mathrm{A}}$ receptor-mediated inhibition in the trigeminal thalamocortical pathway of mice lacking active Met in the cerebral cortex. Furthermore, in contrast to wild-type mice, insulin failed to increase $\mathrm{GABA}_{\mathrm{A}}$ receptor-mediated response in the barrel cortex of mice with compromised Met signaling. Thus, lacking insulin effects may be a risk factor in ASD pathogenesis.

Key words: autism; GABA-A receptor; inhibition; insulin; Met tyrosine kinase; thalamocortical

Significance Statement

A proposed common cause of neurodevelopmental disorders is an imbalance in excitatory neural transmission, provided by the glutamatergic neurons, and the inhibitory signals from the GABAergic interneurons. Many genes associated with autism spectrum disorders impair synaptic transmission in the expected cell type. Previously, inactivation of the autism-associated Met tyrosine kinase receptor in GABAergic interneurons led to decreased inhibition. In thus report, decreased Met signaling in glutamatergic neurons had no effect on excitation, but decimated inhibition. Further experiments indicate that loss of Met activity downregulates $\mathrm{GABA}_{\mathrm{A}}$ receptors on glutamatergic neurons in an insulin independent manner. These data provide a new mechanism for the loss of inhibition and subsequent abnormal excitation/inhibition balance and potential molecular candidates for treatment or prevention.

\section{Introduction}

In the most recent version of the Diagnostic and Statistical Manual of Mental Disorders (DSM-5; American Psychiatric Association, 2013), sensory reactivity symptoms are included in the domain of restricted and repetitive behaviors for the diagnosis of autism spectrum disorder (ASD). The sensory reactivity symptoms are classified as hyperreactivity to sensory input, such as "adverse responses to stimuli," or hyporeactivity, which may include an "indifference" to pain or heat, and finally as seeking behavior or a "fascination with stimuli," such as repeated smell-

\footnotetext{
Received Jan. 2, 2016; revised Feb. 9, 2016; accepted Feb. 22, 2016.

Author contributions:F.-S.L., R.S.E., and E.M.P. designed research;F.-S.L. performed research; E.M.P. contributed unpublished reagents/analytic tools; F.-S.L. analyzed data; F.-S.L., R.S.E., and E.M.P. wrote the paper.

This work was supported by NIH Grant NSO92216.

The authors declare no competing financial interests.

Correspondence should be addressed to Dr. Elizabeth M. Powell, 20 Penn Street, Health Sciences Facility II S251,

Department of Anatomy and Neurobiology, School of Medicine, University of Maryland, Baltimore, MD 21201.

E-mail: epowell@som.umaryland.edu.

DOI:10.1523/JNEUROSCI.0006-16.2016

Copyright $\odot 2016$ the authors $\quad 0270-6474 / 16 / 363691-07 \$ 15.00 / 0$
}

ing or tactile actions. Multiple measures of sensory responses report that $60-80 \%$ of boys with ASD have sensory reactivity symptoms, compared to nearly none $(<4 \%)$ in typically developing boys (Tavassoli et al., 2016). The affected sensory modalities are varied, but about one-third of the children presented with hyperreactive responses to tactile stimulation. Previously, two independent studies reported that sensory impairments in children with ASD result from a functional deficit in the somatosensory inhibitory system (Puts et al., 2014; Tavassoli et al., 2016). In addition, impaired sensory modulation appears to be a common characteristic of childhood developmental disorders, including epilepsy and attention deficit hyperactivity disorder (Baum et al., 2015; van Campen et al., 2015).

The cellular mechanisms underlying sensory deficits of ASD are still not fully understood. The somatosensory cortex is at the center of sensory modulation, receiving information from the environment via the thalamocortical afferents and processing the signals for motor responses or distribution association cortices with cognitive and executive functions. The rodent whiskersensory trigeminal central pathway is an established model for 
studying thalamocortical synaptic development and plasticity. Therefore, by studying alterations in somatosensation in mice that harbor genetic variants akin to those found in human neurodevelopmental disorders, new pathways to treatment or prevention can be found.

Previous studies have implicated hundreds of genetic variants associated with ASD (Sahin and Sur, 2015). Many of the genes linked to "monogenic" forms of syndromic ASD converge on common pathways that are involved in synaptic development, plasticity, and signaling (Ebrahimi-Fakhari and Sahin, 2015). Likewise, susceptibility alleles and environmental causes may lead to perturbations in neural circuitry. Individuals with the autism risk allele of the MET tyrosine kinase receptor gene demonstrated reduced cortical connectivity and function in temporal and parietal areas (Rudie et al., 2012a,b), leading to the question of the role of MET in sensory processing. Using a conditional transgenic (Cre-LoxP) approach, the loss of the signaling domain of Met in GABAergic interneurons and dorsal striatum impaired goal-directed learning (Martins et al., 2011). Loss of Met signaling in the mouse cerebral cortex [using the floxed Met mouse (Met-fx) with the cerebral cortical and hippocampal specific Emx1-cre mouse, denoted as the Met-Emx1 mouse] yielded anatomical changes (Smith et al., 2012) similar to those reported in individuals with the autism-associated " $\mathrm{C}$ " risk allele of MET (Hedrick et al., 2012). In the current study, we used an in vitro thalamocortical slice preparation of wild-type (WT) and MetEmx1 littermates to reveal cellular mechanisms underlying sensory deficits related to ASD. Our results show that the balance of excitation/inhibition (E/I) in the thalamocortical transmission in Met-Emx1 mice is biased toward excitation, due to a dramatic reduction of postsynaptic inhibition most likely caused by diminished postsynaptic $\mathrm{GABA}_{\mathrm{A}}$ receptor density. In contrast with WT mice, insulin fails to enhance $\mathrm{GABA}_{\mathrm{A}}$ receptor-mediated response, implying a role for insulin signaling in the sensory deficits observed in neurodevelopmental disorders.

\section{Materials and Methods}

Mice. Emx1-Cre (K. Jones, University of Colorado, Boulder, CO) and Met- $f x$ mice (S. Thorgeirsson, National Cancer Institute, NIH) were generous gifts from collaborators and backcrossed for $>20$ generations onto the C57BL/6J strain (Jackson Laboratory). Mice used in these experiments were littermates from matings between nonsibling WT and heterozygote $(\mathrm{f} x / \mathrm{Cre})$ mice. All mice were genotyped via PCR using the following primer sets: Met- $f x$ primers 5' -TTA GGC AAT GAG GTG TCC CAC-3' and 5' -CCA GGT GGC TTC AAA TTC TAA GG- 3' (380 bp for the floxed allele and $300 \mathrm{bp}$ for wild-type); Emx1-Cre primers $5^{\prime}$ CACCCTGTTACGTATAGCCG-3' and 5'-GAGTCATCCTTAGCGCCG TA-3' (320 bp; Smith et al., 2012). WT (control) mice included the EmxlCre allele alone, the Met- $f x$ allele alone, and mice lacking any transgenes. No differences have been observed between these control groups. All animal procedures were in accordance with the National Institute of Health Guide for the Care and Use of Laboratory Animals (NIH Publications No. 80-23, revised in 1996) and under approval of the University of Maryland Animal Use and Care Committee.

Brain slice preparation. Brains were removed from 2- to 4-week-old anesthetized mice of either sex and immersed in ice-cold sucrose ACSF containing the following (in $\mathrm{mm}$ [SCAP]): $25 \mathrm{NaHCO}_{3}, 11$ glucose, 234 sucrose, $2.5 \mathrm{KCl}, 1.25 \mathrm{NaHPO}_{4}, 0.5 \mathrm{CaCl}_{2}, 10 \mathrm{MgSO}_{4}, 5.0 \mathrm{Na}-\mathrm{L}-$ ascorbate, 3 Na-pyruvate, 2 thiourea, and 0.5 Myo-inositol. Then, 350 $\mu \mathrm{m}$ thalamocortical slices were cut in sucrose ACSF $\left(\sim 4^{\circ} \mathrm{C}\right)$ with a vibratome (Campden $7000 \mathrm{smz}$ ) at an angle of $50-55^{\circ}$ from the midsagittal plane and $10^{\circ}$ from the coronal plane (Agmon and Connors, 1992; Lee et al., 2005). After $30 \mathrm{~min}$ incubation in sucrose ACSF at $34^{\circ} \mathrm{C}$, the slices were kept at room temperature for at least $1 \mathrm{~h}$. The slice containing the thalamocortical pathway was placed in a submerged-type recording chamber (27 L, Warner Instruments) and continuously perfused ( $>2$ $\mathrm{ml} / \mathrm{min}$ ) with normal ACSF [containing (in $\mathrm{mM}$ ) $126 \mathrm{NaCl}, 3 \mathrm{KCl}, 1.25$ $\mathrm{NaH}_{2} \mathrm{PO}_{4}, 1 \mathrm{MgSO}_{4}, 26 \mathrm{NaHCO}_{3}, 10$ glucose, $2 \mathrm{CaCl}_{2}, 2 \mathrm{Na}$-pyruvate, $1.3 \mathrm{~L}$-ascorbic acid, and 3 Myo-inositol, $\mathrm{pH}$ 7.4] at room temperature. Under these conditions, corticocortical circuits were inactivated such that the excitatory thalamic synapse onto the layer IV neurons could be isolated and studied (Lee and Sherman, 2008).

Electrophysiology. Whole-cell-patch micropipettes were pulled horizontally in three stages from borosilicate glass (WPI, K150F-4) with a P-87 puller (Sutter Instrument). The patch electrodes were backfilled with a Cs-based intracellular solution [containing (in $\mathrm{mM}$ ) 115 $\mathrm{CsMeSO}_{3}, 10 \mathrm{NaCl}, 1 \mathrm{KCl}, 4 \mathrm{MgCl}_{2}, 1 \mathrm{CaCl}_{2}, 11$ EGTA, 20 HEPES, 3 $\mathrm{Na}_{2}$-ATP, and $\left.0.5 \mathrm{Na}_{2}-\mathrm{GTP}, \mathrm{pH} 7.25,>290 \mathrm{mOsm}\right]$ with a tip resistance of 5-9 M $\Omega$. Layer IV excitatory neurons (spiny stellate and star pyramid cells) of the barrel cortex were patched to form whole-cell configuration. Depolarizing current pulses were passed through the patch pipette to identify firing pattern of layer IV excitatory neurons (Agmon and Connors, 1992; Feldmeyer et al., 1999; Beierlein et al., 2003) in current-clamp mode. A concentric stimulating electrode (FHC, CBFP J50) was inserted into the ventrobasal complex of the thalamus (VB) or the internal capsule (IC; Sun et al., 2006). Electrical pulses (0.3 ms duration, $0.33 \mathrm{~Hz}$ ) were passed through the electrode to evoke postsynaptic responses in both current- and voltage-clamp mode. All biological data were acquired by Axopatch 200B amplifier and an InstruTECH ITC-16 interface unit and stored on a Dell DM061 computer with the PULSE (HEKA) software program.

Isolation of EPSCs and IPSCs. Stimulation of the VB or IC induced an early inward current (EPSC) followed by an outward current (IPSC) at $-60 \mathrm{mV}$ holding potential. The outward current became smaller as the holding potential changed toward more negative values. When the outward current just disappeared, the holding potential (around $-70 \mathrm{mV}$ ) was defined as the reversal potential of $\mathrm{GABA}_{\mathrm{A}}$ receptor. The remaining inward current without blockade of NMDA receptors was a purely AMPA receptor-mediated EPSC that was blocked by $10 \mu \mathrm{M}$ NBQX, but not by $50 \mu \mathrm{M}$ picrotoxin (PTX). Note that the EPSC showed a single peak and an exponential decay without the late corticocortical excitation. When the holding potential was changed toward more positive values, the inward current became smaller. When the inward current just disappeared, the holding potential (around $0 \mathrm{mV}$ ) was defined as the reversal potential of glutamate receptors. The resulting outward current was the isolated $\mathrm{GABA}_{\mathrm{A}}$ receptor-mediated IPSC that was completely blocked by $50 \mu \mathrm{M}$ PTX, but not by $100 \mu \mathrm{M}$ DL-APV. We averaged 10 traces of EPSCs and IPSCs induced by maximal stimulation and calculated the ratio of AMPA/GABA (E/I) for each neuron.

AMPA receptor (AMPAR)-mediated spontaneous EPSCs (sEPSCs) were recorded at a holding potential of $-70 \mathrm{mV}$. $\mathrm{GABA}_{\mathrm{A}}$ receptormediated spontaneous IPSCs (sIPSCs) were recorded at $0 \mathrm{mV}$. The averaged amplitude of sEPSCs and sIPSCs was measured with MiniAnalysis software. We did not measure the frequency of sEPSCs and sIPSCs, because under our recording conditions, the frequency was irregular. Insulin (500 nM); NBQX (10 $\mu \mathrm{M})$, an AMPA receptor antagonist; DL-APV $(100 \mu \mathrm{M})$, an NMDA receptor antagonist; and PTX $(50 \mu \mathrm{M})$, a $\mathrm{GABA}_{\mathrm{A}}$ receptor antagonist were applied as needed. All chemicals were purchased from Sigma-Aldrich.

Multiple input index analysis. For inhibitory connections, layer IV excitatory neurons were voltage clamped at $0 \mathrm{mV}$. IPSCs were induced by stimulation of the VB at $0.2 \mathrm{~Hz}$ with increasing stimulating intensity from 0 to $500 \mu \mathrm{A}$ at steps of $10 \mu \mathrm{A}$ as described previously (Lo et al., 2011). The peak amplitudes of IPSCs were measured and plotted against stimulus intensity. The amplitude of IPSCs enhanced in a stepwise manner following the increase in stimulus intensity. We first measured the baseline noise of recordings and calculated the SD of the noise. The variation in amplitude of IPSCs was analyzed. If the amplitude of an IPSC was larger than the prior IPSC by more than three times the SD, a "jumping step" was defined, because the fluctuation of IPSCs induced by the same stimulus intensity was always less than three times the noise SD. The number of "jumping steps" [multiple input index (MII)] provided an estimate of the lower limit number of GABAergic neurons that innervate the recorded cortical neuron. 

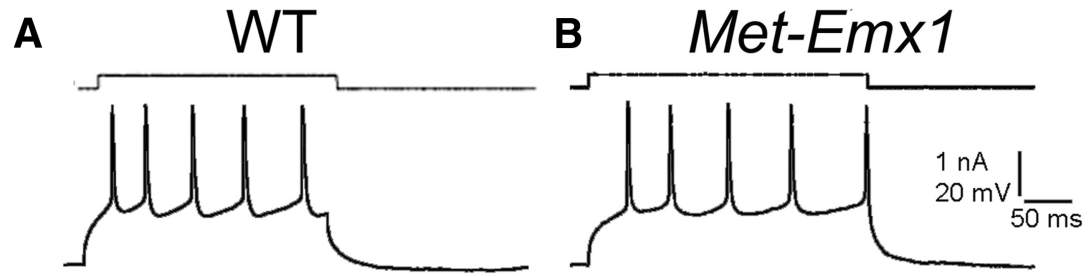

C

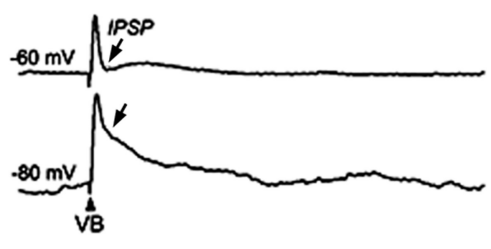

D

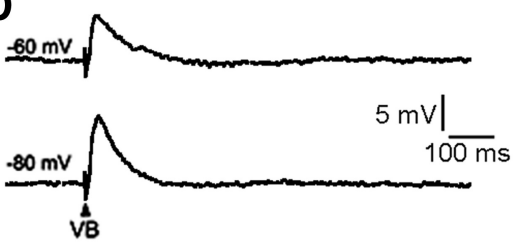

E
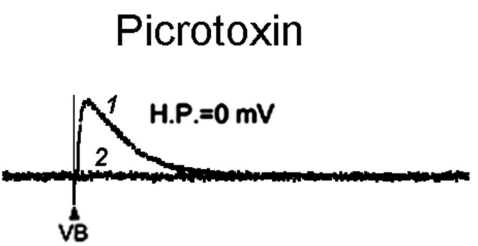

G

$\mathbf{F}$

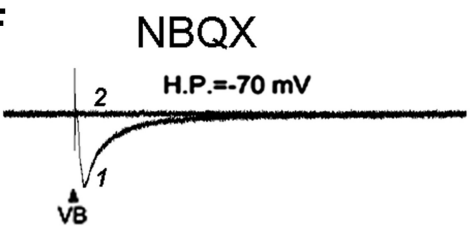

H
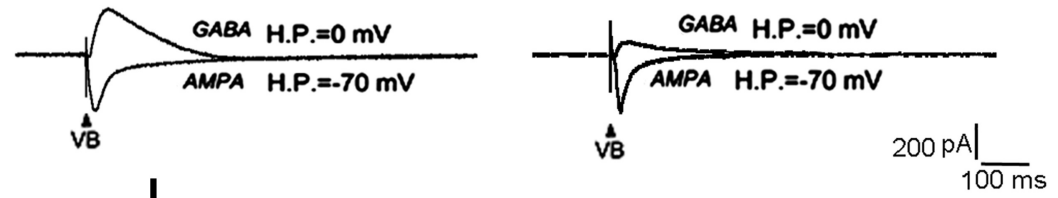

I

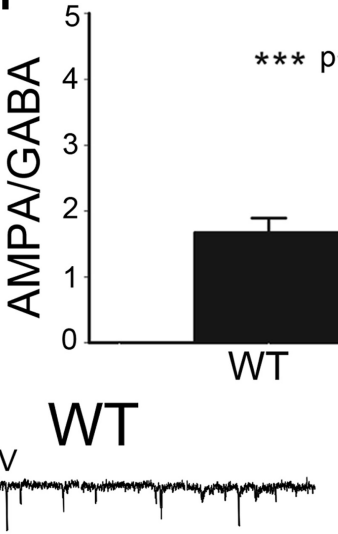

$\mathbf{L}$

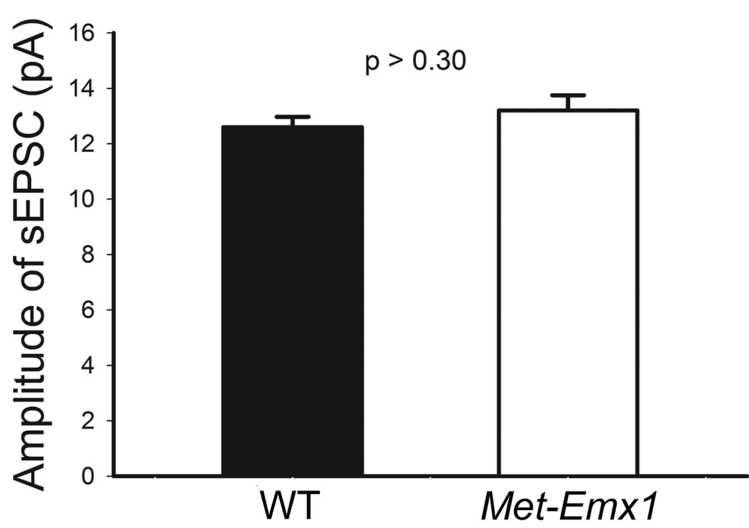

Figure 1. The excitation/inhibition ratio is increased in barrel cortex of Met-Emx1 mice. $\boldsymbol{A}, \boldsymbol{B}$, Layer IV excitatory neurons are identified by an adapting firing pattern in both WT and Met-Emx 1 mice. C, D, Differences in IPSPs between WT and Met-Emx 1 mice. Note that the IPSP, if any, in Met-Emx 1 mice is very small. $E, G A B A_{A}$ receptor-mediated IPSC at $0 \mathrm{mV}$ holding potential is blocked by PTX (trace 1, before application; trace 2, after application). $\boldsymbol{F}$, AMPA receptor-mediated EPSC at $-70 \mathrm{mV}$ holding potential is blocked by NBQX (trace 1 vs trace 2). $\mathbf{G}, \boldsymbol{H}$, Example records of the AMPA/GABA ratio from the same neurons. Note the IPSC is very
Presynaptic transmitter release probability in the inhibitory pathway. Layer IV excitatory neurons were voltage clamped at $0 \mathrm{mV}$ to get $\mathrm{GABA}_{\mathrm{A}}$ receptor-mediated IPSCs induced by two stimuli to the VB at an interval of $200 \mathrm{~ms}$. We averaged 10 trials and calculated the paired-pulse ratio (PPR) of IPSCs by IPSC2/ IPSC1. The PPR of IPSCs depends on presynaptic terminal release probability of the VB to GABAergic interneurons and interneurons to recorded layer IV excitatory neurons, because the IPSC is mainly mediated by a disynaptic pathway.

Data analysis. All data are expressed as mean \pm SEM, and significance was determined by the Student's $t$ test. Spontaneous IPSCs were measured with MiniAnalysis software.

\section{Results}

Diminished inhibition in Met-Emxl mouse somatosensory barrel cortex layer IV excitatory neurons

We compared the current-clamp recordings from WT and Met-Emx1 mouse layer IV excitatory neurons, as identified by the adapting firing pattern (regular spiking) induced by membrane depolarization (Fig. $1 A, B$ ). Stimulation of the VB evoked an EPSP-IPSP sequence in WT neurons. At $-60 \mathrm{mV}$, the IPSP just curtailed the EPSP, but never hyperpolarized the membrane below $-60 \mathrm{mV}$ (Fig. $1 C$, arrow, top trace), indicating that the amplitude of the EPSP was equal to or greater than that of the IPSP. The IPSP was reversed in direction at $-80 \mathrm{mV}$ (Fig. 1C, bottom), suggesting that the reversal potential of the IPSP was approximately $-70 \mathrm{mV}$ (reversal potential of $\mathrm{GABA}_{\mathrm{A}}$ receptor). However, postsynaptic potentials in layer IV Met-Emx1 excitatory neurons were strikingly different from those in WT cells. As shown in Figure $1 D$, there were no clear IPSPs at either -60 or $-80 \mathrm{mV}$, suggesting that the amplitude of the IPSP, if any, is very small. These results indicate a notable change in E/I balance in layer IV excitatory Met-Emx1 mouse neurons.

Next, we quantified the E/I ratio by voltage clamping the membrane at reversal potentials of glutamate $(\sim 0 \mathrm{mV})$ and $\mathrm{GABA}_{\mathrm{A}}$ receptors (approximately $-70 \mathrm{mV}$ ) to isolate pure $\mathrm{GABA}_{\mathrm{A}}$ receptor-mediated IPSC (GABA) and AMPA receptor-mediated EPSC (AMPA). Figure $1 E$ is an example record at $0 \mathrm{mV}$ holding potential. VB stimulation induces a pure $\mathrm{GABA}_{\mathrm{A}}$ receptor-

$\leftarrow$

small in amplitude in Met-Emx1 mice. I, The averaged AMPA/ GABA (excitation/inhibition) ratio in Met-Emx1 mice is much larger than that of WT mice. $\boldsymbol{J}, \boldsymbol{K}$, Example records of sEPSCS from WT and Met-Emx 1 mice. $L$, Averaged amplitude of sEPSCS of WT mice is about the same as that of Met-Emx1 mice. 
mediated IPSC that is completely blocked by PTX (trace 1 before vs trace 2 after). Figure $1 F$ is an example record at $-70 \mathrm{mV}$ holding potential. VB stimulation induces an AMPA receptor-mediated EPSC that is completely blocked by NBQX (trace 1 vs trace 2 ). Then the ratio of the amplitudes of the AMPA receptor-mediated EPSC and $\mathrm{GABA}_{\mathrm{A}}$ receptor-mediated IPSC (AMPA/GABA) induced by maximal stimulation from each neuron can be calculated. Example records from WT and Met-Emx1 neurons are shown in Figure 1, G and $H$. Note that the IPSC of Met-Emxl neurons is remarkably small. The averaged AMPA/GABA ratio was $1.67 \pm 0.22(n=11)$ for WT cells (Fig. 1I, black bar). The ratio in Met-Emxl cells was $3.53 \pm$ $0.43(n=8)$, which was significantly $(p<0.001)$ larger than that in WTs (Fig. 1I, white bar).

The increase in the E/I ratio of Met-Emxl mice may result from either increased excitation or decreased inhibition. We compared the averaged amplitude of AMPAR-mediated sEPSCs between WT and Met-Emxl neurons and found no significant difference between the two genotypes (Fig. $1 \mathrm{~J}, K$ ). The averaged amplitude of sEPSCs in Met-Emx1 neurons (13.24 $\pm 0.55 \mathrm{pA}$, $n=224$ from five neurons) was the same as that from WT neurons $(12.58 \pm 0.37 \mathrm{pA}, n=383$ from seven neurons, $p>0.30$; Fig. $1 L$ ). In summary, in the thalamocortical pathway of barrel cortex of the Met-Emxl mouse, the E/I balance is biased toward excitation, likely due to decreased inhibition.

\section{Inhibitory neural network in the barrel cortex of the Met-}

Emx1 mouse remains unchanged

The decrease in postsynaptic inhibition in Met-Emx1 mouse barrel cortex may be caused by loss of presynaptic inhibitory inputs. Layer IV excitatory cells receive feedforward and feedback inhibition from layer IV GABAergic interneurons (Beierlein et al., 2003; Gabernet et al., 2005; Sun et al., 2006). We used MII analysis to estimate the lower limit number of GABAergic neurons that innervate recorded layer IV excitatory neurons. The amplitude of IPSCs in Met-Emxl mice is smaller than in WT mice (Fig. $2 A, B)$, but the number of steps is the same. The averaged MII of IPSCs in the WT mouse was $4.10 \pm 0.18(n=9$; Fig. $2 C$, black bar), whereas that of Met-Emx1 mouse was not significantly different, $4.83 \pm 0.40(p>0.05, n=6$; Fig. $2 C$, white bar $)$. This finding suggests that the density (or number) of GABAergic interneurons in layer IV of barrel cortex is not changed in the context of decreased Met activity.

Presynaptic transmitter release probability in the inhibitory pathway is not altered

The decreased postsynaptic inhibition may result from a reduction of transmitter release probability from the presynaptic terminal. We used a paired-pulse protocol to calculate the PPR of IPSCs (Fig. $2 D, E$ ). The averaged PPR of IPSCs in WT mice was $0.94 \pm 0.02(n=9)$, and in Met-Emx1 mice the PPR was similar to that for WTs $0.92 \pm 0.03(n=19, p>0.57$; Fig. $2 F)$, despite a smaller IPSC amplitude. Thus, impaired Met signaling does not alter the presynaptic release function of the inhibitory pathway in the Met-Emx1 mouse.

$\mathrm{GABA}_{\mathrm{A}}$ receptor function in the barrel cortex of Met mice is decreased and insulin independent

Because there was no observed change in the presynaptic inhibitory pathway in the Met-Emxl barrel cortex, the decrease in inhibition may result from absence or paucity of postsynaptic $\mathrm{GABA}_{\mathrm{A}}$ receptors on the excitatory neurons. We compared the amplitude of sIPSCs between WT and Met-Emx1 mice (Fig. $2 G, H)$. The averaged amplitude of sIPSC for the WT mouse was
A

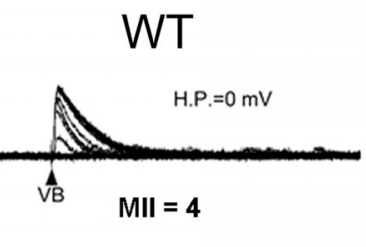

B $\quad$ Met-Emx1

C

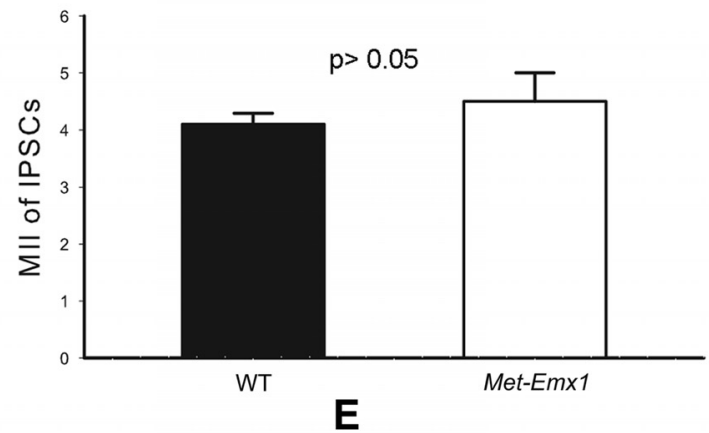

D
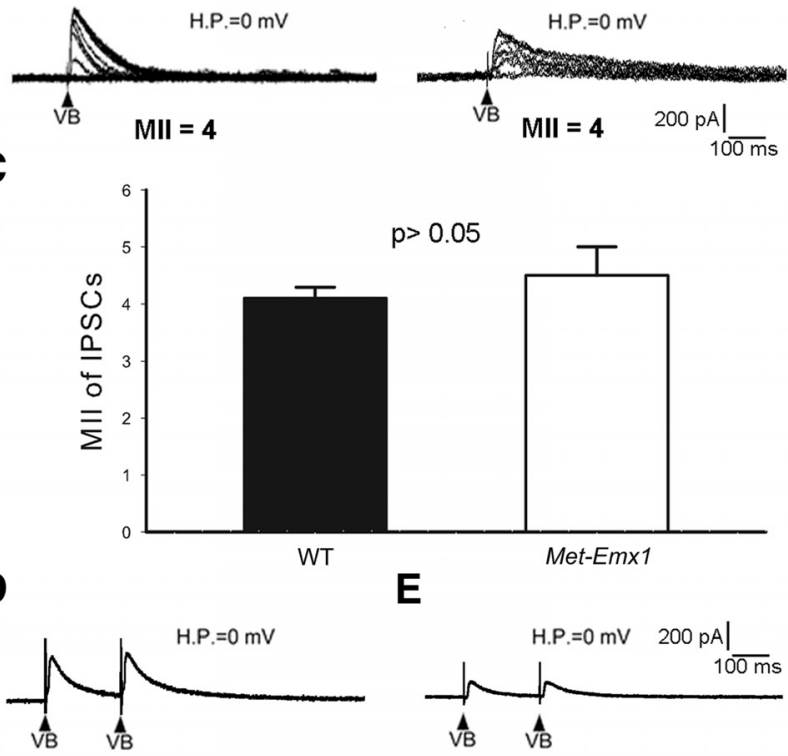

$\mathbf{F}$

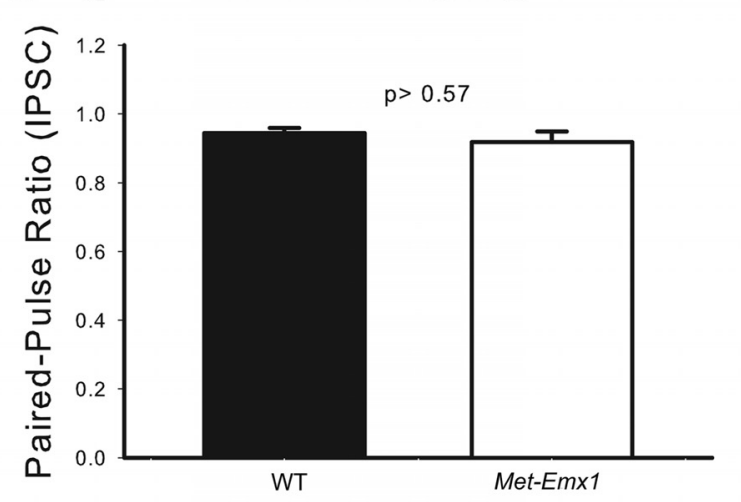

G

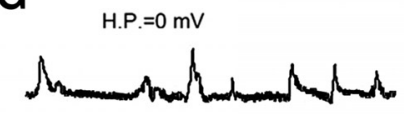

H

I
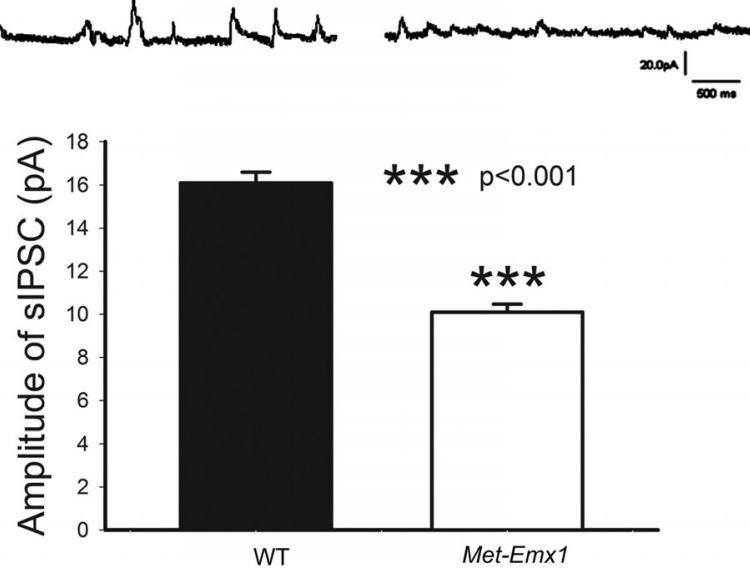

Figure 2. Mechanisms underlying decreased inhibition in the barrel cortex of Met-Emx 1 mice. $A$, $B$, Example records of MII of IPSCS in both WT and Met-Emx1 mice. C, No significant difference in average MII of IPSCS between WT and Met-Emx 1 mice. $\boldsymbol{D}, \boldsymbol{E}$, Example records of PPR of IPSCS. $\boldsymbol{F}$, No significant difference in PPR of IPSCs between WT and Met-Emx1 mice. $\boldsymbol{G}, \boldsymbol{H}$, Example records of sIPSCS.I, The average amplitude ofsIPSCsin Met-Emx 1 miceis significantlysmallert than thatin WTmice.

$16.10 \pm 0.47 \mathrm{pA}$ ( $n=238$ from five neurons; Fig. $2 I$, black bar), whereas a significantly smaller amplitude of sIPSC was found for Met-Emx 1 cortex, $10.10 \pm 0.37 \mathrm{pA}(p<0.001, n=295$ from six neurons; Fig. 2I, white bar), suggesting that the density of post- 
WT

A

Insulin

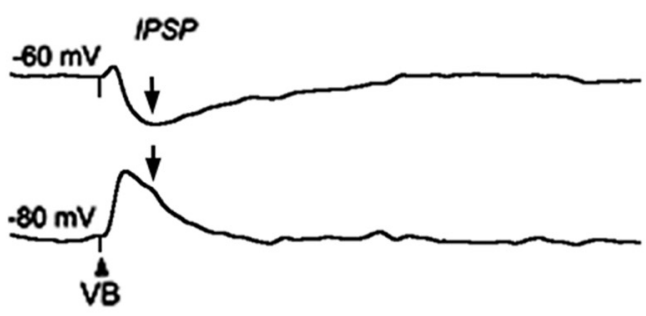

C

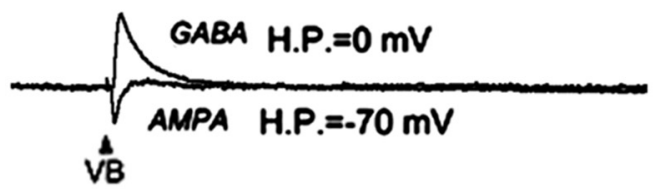

E

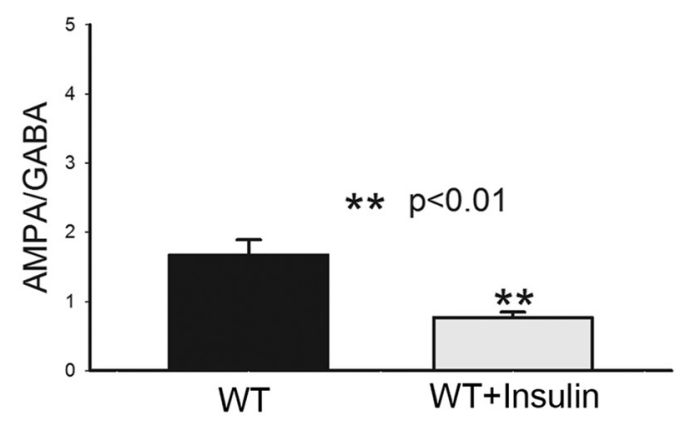

G

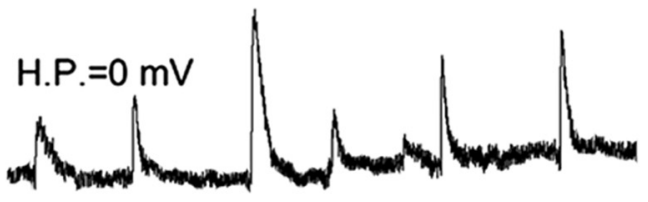

H

D
Met-Emx1

B Insulin
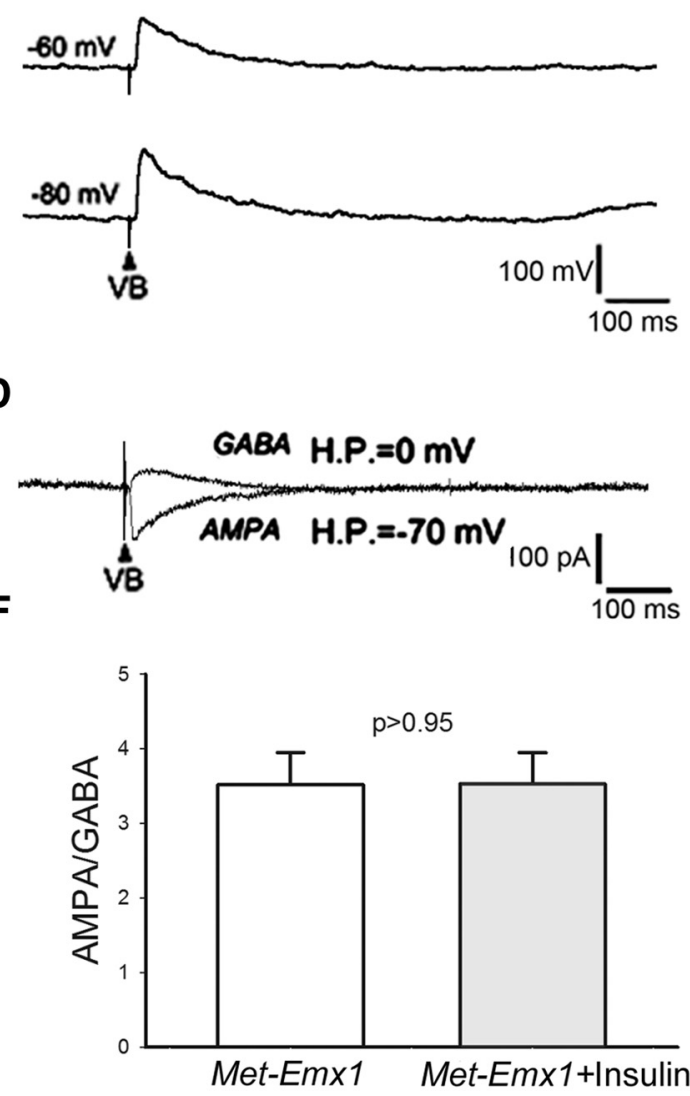

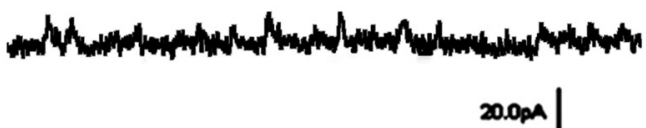

$\overline{500 \mathrm{~ms}}$

J

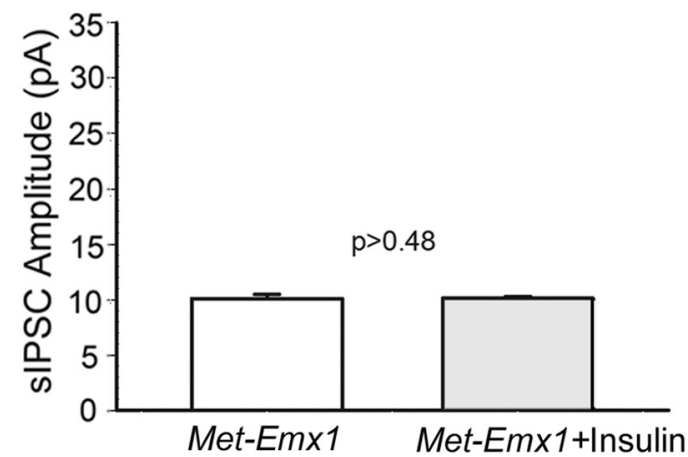

Figure 3. Neurons in the barrel cortex of Met-Emx1 mice do not respond to insulin. $A, C$, In WT mice, insulin increases the amplitude of IPSP and IPSC. $E$, Insulin decreases the averaged AMPA/GABA ratio in WT mice. $G, I$, The amplitude of $s$ IPSCS is enhanced by application of insulin in WT mice. $\boldsymbol{B}, \boldsymbol{D}$, In Met-Emx 1 mice, insulin fails to increase the amplitude of the IPSP and IPSC. $\boldsymbol{F}$, The averaged AMPA/GABA ratio is not altered by application of insulin in Met-Emx 1 mice. $\boldsymbol{H}, \boldsymbol{J}$, Insulin does not change the amplitude of sIPSCs in Met-Emx 1 mice. 
synaptic $\mathrm{GABA}_{\mathrm{A}}$ receptors is probably reduced in the barrel cortex of Met-Emx1 mice (Otis et al., 1994; Nusser et al., 1997, 1998).

To increase postsynaptic $\mathrm{GABA}_{\mathrm{A}}$ receptor-mediated response, we tested the effect of insulin. Brain insulin regulates brain functions, including synaptic plasticity, by modulating excitatory and inhibitory postsynaptic neurotransmitter receptor trafficking (Kovacs and Hajnal, 2009; Duarte et al., 2012). Insulin also promotes surface expression (exocytosis) of $\mathrm{GABA}_{\mathrm{A}}$ receptors in cultured hippocampal neurons (Wan et al., 1997; Mielke and Wang, 2005). Therefore, we tested whether insulin could restore the inhibition in the thalamocortical slice preparation.

In WT mice, the presence of insulin ( $500 \mathrm{~nm})$, VB stimulation induced an EPSP-IPSP sequence. However, at $-60 \mathrm{mV}$, the IPSP hyperpolarized the membrane below the base line (compare Figs. $1 C$, top traces, $3 A$ ), suggesting that in the presence of insulin, the amplitude of the EPSP is less than that of the IPSP. The IPSP is reversed toward $-80 \mathrm{mV}$ (Fig. $3 A$, bottom trace), suggesting that the IPSP is mediated by $\mathrm{GABA}_{\mathrm{A}}$ receptors. Insulin decreased the AMPA/GABA ratio markedly by enhancing IPSC amplitude in WT mice (compare Figs. $1 G, 3 C$ ). The averaged AMPA/GABA ratio in the presence of insulin was $0.77 \pm 0.08(n=8$; Fig. $3 E$, gray bar), which was significantly $(p<0.01)$ smaller than without insulin, $1.67 \pm 0.22(n=11$; Fig. $3 E$, black bar). The application of insulin led to an increase in amplitude of sIPSCs (compare Figs. $1 G, 3 G$ ), and the average amplitude of sIPSCs, $16.10 \pm 0.47 \mathrm{pA}$ ( $n=238$ from five neurons; Fig. 3I, black bar), was significantly enhanced by insulin $(27.48 \pm 1.87 \mathrm{pA}, p<$ $0.001, n=149$ from four neurons; Fig. 3I, gray bar). Thus, applied insulin increased inhibition in WT barrel cortex.

In sharp contrast, insulin failed to change the inhibitory response in barrel cortex, in which Met activation is impaired. In the presence of insulin, VB stimulation-induced postsynaptic responses did not show a clear IPSP at -60 or $-80 \mathrm{mV}$ (compare Figs. $1 D, 3 B$ ). The voltage-clamped $\mathrm{GABA}_{\mathrm{A}}$ receptor-mediated IPSC was not increased (Figs. $1 H, 3 D$ ). The averaged AMPA/ GABA ratio for Met-Emx1 cortex was $3.53 \pm 0.43(n=8$; Fig. $3 F$, white bar); however, application of insulin did not alter the AMPA/GABA ratio $(3.53 \pm 0.42, n=5$; Fig. $3 F$, gray bar, $p>$ 0.95). Similarly, the amplitude of sIPSCs in Met-Emx1 mice remained the same after the addition of insulin (compare Figs. $2 \mathrm{H}$, $3 H)$, with an amplitude of $10.10 \pm 0.37 \mathrm{pA}(n=295$ from six neurons; Fig. 3J, white bar) for control slices compared to $10.11 \pm 0.17 \mathrm{pA}(n=470$ from seven neurons; Fig. 3J, gray bar $)$ for the Met-Emx1 preparation. Taken together, these results indicate that the decreased $\mathrm{GABA}_{\mathrm{A}}$ receptor-mediated response in the Met-Emx1 mouse barrel cortex is not modulated by insulin signaling.

\section{Discussion}

Our results show that in the thalamocortical pathway of MetEmx1 mice, the E/I ratio increases due to a dramatic reduction in postsynaptic inhibition. E/I imbalance is proposed as a cellular mechanism in sensory processing underlying various neurological and psychiatric disorders (for review, see Gatto and Broadie, 2010; Zhang and Sun, 2011). Deficits in inhibition have been proposed as an underlying cause of neurodevelopmental disorders, including autism (Hussman, 2001; Rubenstein and Merzenich, 2003; Levitt et al., 2004). Loss of inhibition or a hyperexcitable cortex is inherently unstable and susceptible to epilepsy (Jacobs et al., 1999). Abnormal inhibitory tone can lead to uncoordinated neuronal firing and loss of encoding in sensory and cognitive tasks (Cellot and Cherubini, 2014; Bissonette et al., 2015). Often the impaired inhibition is due to insufficient num- bers of GABAergic interneurons, and loss of cortical GABAergic interneurons is a common endophenotype of epilepsy and autism spectrum disorders (Blatt and Fatemi, 2011; Enticott et al., 2013; Gaetz et al., 2014) and in mouse models of these disorders (Chao et al., 2010; Martins et al., 2011; Bissonette et al., 2014).

The MET gene has been associated with autism in multiple patient cohorts (Campbell et al., 2006; Jackson et al., 2009; Sousa et al., 2009; Campbell et al., 2010), and certain variants of the promoter region ( $\mathrm{C}$ allele) that decrease transcription and MET expression are considered as susceptibility alleles (Thanseem et al., 2010). Met has been implicated in cerebral cortical GABAergic interneuron ontogeny, and loss of Met activity, specifically in interneurons, impairs cognitive and procedural behaviors (Powell et al., 2001; Martins et al., 2007, 2011). However, in the current study, Met was rendered inactive in glutamatergic neurons and glia in the neocortex and hippocampus (using the Emx1-Cre strategy). Thus, the GABAergic interneuron populations are not expected to be affected, and this prediction is supported by the MII analysis (Fig. 2A-C). Our results further reveal that an increase in E/I ratio in Met-deficient cortex is due to a decreased amplitude of the sIPSCs. A possible explanation for our data is a reduction in postsynaptic $\mathrm{GABA}_{\mathrm{A}}$ receptor density.

In cultured hippocampal neurons, exposure to insulin drives insertion of $\mathrm{GABA}_{\mathrm{A}}$ receptors into the synapse (Wan et al., 1997; Mielke and Wang, 2005). In the WT thalamocortical slice, insulin increases the inhibitory response of layer IV neurons in response to $\mathrm{VB}$ stimulation (Fig. $3 A, E$ ). However, in the Met-Emx1 mouse, insulin has no effect on the AMPA/GABA ratio (Fig. $3 F$ ), implying that insulin is not capable of recruiting the $\mathrm{GABA}_{\mathrm{A}}$ receptors in barrel cortex. In the hippocampus CA1, insulin induces long-term depression (LTD) that is similar to ASDimplicated metabotropic glutamate receptor-mediated LTD via PI3K and mTOR activity. Stern (2011) hypothesized that insulin signaling contributes to the development of autism in genetically susceptible individuals by contributing to $\mathrm{PI} 3 \mathrm{~K} / \mathrm{mTOR}$ pathway activation in neurons. Our results suggest that $\mathrm{GABA}_{\mathrm{A}}$ receptor trafficking in the barrel cortex of Met-Emxl mice is not sensitive to insulin, and thus insulin resistance may also be a major risk factor for ASD. These findings can pave the way to designing novel therapeutic strategies for ASD, perhaps by modulating the insulin responsiveness of distinct $\mathrm{GABA}_{\mathrm{A}}$ receptors.

\section{References}

Agmon A, Connors BW (1992) Correlation between intrinsic firing patterns and thalamocortical synaptic responses of neurons in mouse barrel cortex. J Neurosci 12:319-329. Medline

American Psychiatric Association (2013) Diagnostic and statistical manual of mental disorders: DSM-5. Washington, DC: American Psychiatric Association.

Baum SH, Stevenson RA, Wallace MT (2015) Behavioral, perceptual, and neural alterations in sensory and multisensory function in autism spectrum disorder. Prog Neurobiol 134:140-160. CrossRef Medline

Beierlein M, Gibson JR, Connors BW (2003) Two dynamically distinct inhibitory networks in layer 4 of the neocortex. J Neurophysiol 90:29873000. CrossRef Medline

Bissonette GB, Bae MH, Suresh T, Jaffe DE, Powell EM (2014) Prefrontal cognitive deficits in mice with altered cerebral cortical GABAergic interneurons. Behav Brain Res 259:143-151. CrossRef Medline

Bissonette GB, Schoenbaum G, Roesch MR, Powell EM (2015) Interneurons are necessary for coordinated activity during reversal learning in orbitofrontal cortex. Biol Psychiatry 77:454-464. CrossRef Medline

Blatt GJ, Fatemi SH (2011) Alterations in GABAergic biomarkers in the autism brain: research findings and clinical implications. Anat Rec 294: 1646-1652. CrossRef

Campbell DB, Sutcliffe JS, Ebert PJ, Militerni R, Bravaccio C, Trillo S, Elia M, Schneider C, Melmed R, Sacco R, Persico AM, Levitt P (2006) A genetic 
variant that disrupts MET transcription is associated with autism. Proc Natl Acad Sci U SA 103:16834-16839. CrossRef Medline

Campbell DB, Warren D, Sutcliffe JS, Lee EB, Levitt P (2010) Association of MET with social and communication phenotypes in individuals with autism spectrum disorder. Am J Med Genet B Neuropsychiatr Genet 153B: 438-446. Medline

Cellot G, Cherubini E (2014) Reduced inhibitory gate in the barrel cortex of Neuroligin3R451C knock-in mice, an animal model of autism spectrum disorders. Physiol Rep 2:e12077. Medline

Chao HT, Chen H, Samaco RC, Xue M, Chahrour M, Yoo J, Neul JL, Gong S, Lu HC, Heintz N, Ekker M, Rubenstein JL, Noebels JL, Rosenmund C, Zoghbi HY (2010) Dysfunction in GABA signalling mediates autismlike stereotypies and Rett syndrome phenotypes. Nature 468:263-269. CrossRef Medline

Duarte AI, Moreira PI, Oliveira CR (2012) Insulin in central nervous system: more than just a peripheral hormone. J Aging Res 2012:384017. Medline

Ebrahimi-Fakhari D, Sahin M (2015) Autism and the synapse: emerging mechanisms and mechanism-based therapies. Curr Opin Neurol 28: 91-102. CrossRef Medline

Enticott PG, Kennedy HA, Rinehart NJ, Tonge BJ, Bradshaw JL, Fitzgerald PB (2013) GABAergic activity in autism spectrum disorders: an investigation of cortical inhibition via transcranial magnetic stimulation. Neuropharmacology 68:202-209. CrossRef Medline

Feldmeyer D, Egger V, Lubke J, Sakmann B (1999) Reliable synaptic connections between pairs of excitatory layer 4 neurones within a single 'barrel' of developing rat somatosensory cortex. J Physiol 521:169-190. CrossRef Medline

Gabernet L, Jadhav SP, Feldman DE, Carandini M, Scanziani M (2005) Somatosensory integration controlled by dynamic thalamocortical feedforward inhibition. Neuron 48:315-327. CrossRef Medline

Gaetz W, Bloy L, Wang DJ, Port RG, Blaskey L, Levy SE, Roberts TP (2014) GABA estimation in the brains of children on the autism spectrum: measurement precision and regional cortical variation. Neuroimage 86:1-9. CrossRef Medline

Gatto CL, Broadie K (2010) Genetic controls balancing excitatory and inhibitory synaptogenesis in neurodevelopmental disorder models. Front Synaptic Neurosci 2:4. Medline

Hedrick A, Lee Y, Wallace GL, Greenstein D, Clasen L, Giedd JN, Raznahan A (2012) Autism risk gene MET variation and cortical thickness in typically developing children and adolescents. Autism Res 5:434-439. CrossRef Medline

Hussman JP (2001) Suppressed GABAergic inhibition as a common factor in suspected etiologies of autism. J Autism Dev Disord 31:247-248. CrossRef Medline

Jackson PB, Boccuto L, Skinner C, Collins JS, Neri G, Gurrieri F, Schwartz CE (2009) Further evidence that the rs $1858830 \mathrm{C}$ variant in the promoter region of the MET gene is associated with autistic disorder. Autism Res 2:232-236. CrossRef Medline

Jacobs KM, Kharazia VN, Prince DA (1999) Mechanisms underlying epileptogenesis in cortical malformations. Epilepsy Res 36:165-188. CrossRef Medline

Kovacs P, Hajnal A (2009) In vivo electrophysiological effects of insulin in the rat brain. Neuropeptides 43:283-293. CrossRef Medline

Lee CC, Sherman SM (2008) Synaptic properties of thalamic and intracortical inputs to layer 4 of the first- and higher-order cortical areas in the auditory and somatosensory systems. J Neurophysiol 100:317-326. CrossRef Medline

Lee LJ, Iwasato T, Itohara S, Erzurumlu RS (2005) Exuberant thalamocortical axon arborization in cortex-specific NMDAR1 knockout mice. J Comp Neurol 485:280-292. CrossRef Medline

Levitt P, Eagleson KL, Powell EM (2004) Regulation of neocortical interneuron development and the implications for neurodevelopmental disorders. Trends Neurosci 27:400-406. CrossRef Medline

Lo FS, Zhao S, Erzurumlu RS (2011) Astrocytes promote peripheral nerve injury-induced reactive synaptogenesis in the neonatal CNS. J Neurophysiol 106:2876-2887. CrossRef Medline

Martins GJ, Plachez C, Powell EM (2007) Loss of embryonic MET signaling alters profiles of hippocampal interneurons. Dev Neurosci 29:143-158. CrossRef Medline

Martins GJ, Shahrokh M, Powell EM (2011) Genetic disruption of Met sig- naling impairs GABAergic striatal development and cognition. Neuroscience 176:199-209. CrossRef Medline

Mielke JG, Wang YT (2005) Insulin exerts neuroprotection by counteracting the decrease in cell-surface GABA receptors following oxygen-glucose deprivation in cultured cortical neurons. J Neurochem 92:103-113. CrossRef Medline

Nusser Z, Cull-Candy S, Farrant M (1997) Differences in synaptic GABA(A) receptor number underlie variation in GABA mini amplitude. Neuron 19:697-709. CrossRef Medline

Nusser Z, Hájos N, Somogyi P, Mody I (1998) Increased number of synaptic GABA(A) receptors underlies potentiation at hippocampal inhibitory synapses. Nature 395:172-177. CrossRef Medline

Otis TS, De Koninck Y, Mody I (1994) Lasting potentiation of inhibition is associated with an increased number of gamma-aminobutyric acid type A receptors activated during miniature inhibitory postsynaptic currents. Proc Natl Acad Sci U S A 91:7698-7702. CrossRef Medline

Powell EM, Mars WM, Levitt P (2001) Hepatocyte growth factor/scatter factor is a motogen for interneurons migrating from the ventral to dorsal telencephalon. Neuron 30:79-89. CrossRef Medline

Puts NA, Wodka EL, Tommerdahl M, Mostofsky SH, Edden RA (2014) Impaired tactile processing in children with autism spectrum disorder. J Neurophysiol 111:1803-1811. CrossRef Medline

Rubenstein JL, Merzenich MM (2003) Model of autism: increased ratio of excitation/inhibition in key neural systems. Genes Brain Behav 2: 255-267. CrossRef Medline

Rudie JD, Brown JA, Beck-Pancer D, Hernandez LM, Dennis EL, Thompson PM, Bookheimer SY, Dapretto M (2012a) Altered functional and structural brain network organization in autism. Neuroimage Clin 2:79-94. Medline

Rudie JD, Hernandez LM, Brown JA, Beck-Pancer D, Colich NL, Gorrindo P, Thompson PM, Geschwind DH, Bookheimer SY, Levitt P, Dapretto M (2012b) Autism-associated promoter variant in MET impacts functional and structural brain networks. Neuron 75:904-915. CrossRef Medline

Sahin M, Sur M. (2015) Genes, circuits, and precision therapies for autism and related neurodevelopmental disorders. Science 350: pii: aab3897. CrossRef Medline

Smith JM, Xu J, Powell EM (2012) Age dependent forebrain structural changes in mice deficient in the autism associated gene Met tyrosine kinase. Neuroimage Clin 1:66-74. CrossRef Medline

Sousa I, Clark TG, Toma C, Kobayashi K, Choma M, Holt R, Sykes NH, Lamb JA, Bailey AJ, Battaglia A, Maestrini E, Monaco AP (2009) MET and autism susceptibility: family and case-control studies. Eur J Hum Genet 17:749-758. CrossRef Medline

Stern M (2011) Insulin signaling and autism. Front Endocrinol 2:54. Medline

Sun QQ, Huguenard JR, Prince DA (2006) Barrel cortex microcircuits: thalamocortical feedforward inhibition in spiny stellate cells is mediated by a small number of fast-spiking interneurons. J Neurosci 26:1219-1230. CrossRef Medline

Tavassoli T, Bellesheim K, Siper PM, Wang AT, Halpern D, Gorenstein M, Grodberg D, Kolevzon A, Buxbaum JD (2016) Measuring sensory reactivity in autism spectrum disorder: application and simplification of a clinician-administered sensory observation scale. J Autism Dev Disord 46:287-293. CrossRef Medline

Thanseem I, Nakamura K, Miyachi T, Toyota T, Yamada S, Tsujii M, Tsuchiya KJ, Anitha A, Iwayama Y, Yamada K, Hattori E, Matsuzaki H, Matsumoto K, Iwata Y, Suzuki K, Suda S, Kawai M, Sugihara G, Takebayashi K, Takei N, et al. (2010) Further evidence for the role of MET in autism susceptibility. Neurosci Res 68:137-141. CrossRef Medline

van Campen JS, Jansen FE, Kleinrensink NJ, Joëls M, Braun KP, Bruining H (2015) Sensory modulation disorders in childhood epilepsy. J Neurodev Disord 7:34. CrossRef Medline

Wan Q, Xiong ZG, Man HY, Ackerley CA, Braunton J, Lu WY, Becker LE, MacDonald JF, Wang YT (1997) Recruitment of functional GABA(A) receptors to postsynaptic domains by insulin. Nature 388:686-690. CrossRef Medline

Zhang Z, Sun QQ (2011) The balance between excitation and inhibition and functional sensory processing in the somatosensory cortex. Int Rev Neurobiol 97:305-333. CrossRef Medline 